\title{
The Swiss Policy Agendas Project
}

\author{
Roy Gava, Pascal Sciarini, Anke Tresch, and Frédéric Varone
}

\subsection{The Swiss Political System}

The Swiss political system is peculiar in many respects (for an introduction see Kriesi and Trechsel, 2008). First, Switzerland stands apart regarding its form of government, which is neither parliamentary nor presidential. Second, direct democracy is a central element of Swiss politics. Third, Switzerland has often been characterized as a paradigmatic case of consensus democracy (Lijphart, 1999). Negotiation, compromise, and consensus-building have thus been traditionally considered a hallmark of policymaking.

The Swiss government, the Federal Council, is a seven-member executive body. Since 1959, it has integrated the four major political parties (i.e., Social Democrats, Liberals, Christian Democrats and the Swiss People's Party), systematically accounting for over 70 percent of the electorate. The government is consequently shared by all main parties, which receive a number of seats in the Federal Council that is roughly proportional to their parliamentary strength. Each federal councilor leads a ministry but shares otherwise the same governmental rights and duties. Moreover, the government operates under the collegiality principle. This means that the Federal Council speaks with a single voice: even if a federal councilor disagrees with a governmental decision, he or she is expected to endorse it and defend it vis-à-vis the parliament and the public. The governmental parties are, however, not bound by any coalition agreement. Therefore, governmental parties do not need to behave loyally towards the government and may even play the two-sided game of government and opposition.

The seven federal councilors are elected on an individual basis and for a mandate of four years, by the parliament. Unlike in a parliamentary system, however, they cannot be dismissed before the end of the legislature. The parliament and/or the people (by means of an ex post referendum) may 
well reject government policy proposals, but this does not have any effect on the composition of the Federal Council. Conversely, the government cannot dissolve the parliament or call for new parliamentary elections before the end of the legislature.

Direct democracy is a crucial arena in Switzerland. All popular votes are binding and citizens are called to the ballot box several times per year. Referenda are held either on constitutional amendments or on laws adopted by the parliament. In the former case, the referendum is mandatory and requires a double majority of both the people and the cantons. In the latter case, the referendum is optional, meaning that a vote only takes place if 50,000 citizens sign a referendum against a legislative act (federal laws and, under certain conditions, international treaties). The optional referendum requires only a simple majority of the people in order to succeed, i.e., to prevent the entry into force of the targeted law. Empirically, less than 10 percent of federal laws are challenged by a referendum-and submitted to the people (Sciarini and Tresch, 2014). Finally, citizens may launch a popular initiative to amend the Constitution, if they are able to collect 100,000 signatures. To be accepted, the initiatives also require a double majority of both the people and the twenty-six cantons. The parliament can propose a counter-proposal to the initiative on which the citizens also vote at the same time.

Switzerland has been often seen as the poster child of political stability and consensus democracy. The Swiss political system has nevertheless been through numerous readjustments since the early 1990s, leading scholars to critically revisit the functioning of the consensus model (Sciarini et al., 2015). Recent transformations include the polarization of politics during elections and in parliament, the strategic use of direct democracy by political parties, as well as the internationalization and mediatization of politics and policies. Beyond comparative endeavors, the tracing of issues across time and arenas provides insights into the changing nature of Swiss politics. For instance, such an approach has proven useful to investigate the transformation of the Swiss People's Party into a right-wing populist party (Varone et al., 2014), the impact of Europeanization on domestic politics and legislative production (Gava and Varone, 2012, 2014; Gava et al., 2017), the interaction between media and political agendas (Tresch etal., 2012, 2013; Vliegenthart et al., 2016a), and the interaction between protests, media, and political agendas (Vliegenthart et al., 2016b).

\subsection{Datasets}

Five datasets covering crucial agendas of the Swiss political system have been collected at the Department of Political Science and International Relations of the University of Geneva ${ }^{1}$ following the CAP approach. These datasets allow 
Roy Gava, Pascal Sciarini, Anke Tresch, and Frédéric Varone

Table 18.1. Overview of Swiss Agendas datasets

\begin{tabular}{|c|c|c|c|}
\hline Agenda & Source & Period & $N$ \\
\hline Parliament & Parliamentary interventions & 1995-2003 & 9,949 \\
\hline Government & Legislative proposals & 1978-2008 & 1,951 \\
\hline Legislation & Legislative acts & $1978-2008$ & 1,420 \\
\hline Direct democracy & Popular votes & $1848-2014$ & 605 \\
\hline Media & Newspaper front page & $1995-2003$ & 9,896 \\
\hline
\end{tabular}

Source: Comparative Agendas Project-Switzerland

the study of parliamentary, governmental, legislative, direct democracy, and media agendas (see Table 18.1).

The Swiss parliament is composed of two chambers. The National Council represents the people (200 seats) and the Council of States represents the cantons (26 seats; two for each canton and one for half cantons). Parliamentary interventions materialize the agenda-setting power of the parliament, as well as the parliamentary oversight over the executive. Individual MPs or MPs organized in parliamentary groups and committees can introduce interventions, with no legal limitations in terms of number or scope. Nevertheless, MPs work part-time and usually meet four times a year for three-week sessions. Unlike parliamentary committees, individual MPs can only introduce parliamentary interventions during sessions.

Postulates, motions, and parliamentary initiatives allow MPs to initiate legislative processes. All these interventions are put to a vote, but their agenda-setting power varies considerably. Postulates require the approval of a single chamber. When a postulate is adopted, the government is required to prepare a report or to study whether legislation is required on a given topic. Motions are more constraining. If adopted by both chambers, the government is obliged to draft a bill on a given topic. The parliamentary initiative is the most powerful agenda-setting instrument at the disposal of MPs. Requiring the support of a parliamentary committee and a majority in both chambers, it allows the parliament to draft a bill and to control the decision-making process from start to finish, thus by-passing the executive.

Parliamentary questions and interpellations for the government fulfill a control function, but they also allow MPs to position themselves before the media and the public (Bailer 2011). Written questions can be introduced in both chambers by individual MPs. In addition, there is a parliamentary question hour in the National Council, which takes place at the beginning of the second and third week of each session, and is also used by MPs to draw attention to specific topics.

While MPs can draft legislation by means of a parliamentary initiative, the lion's share of Swiss legislation results from bills prepared and drafted by the executive (Sciarini et al., 2002; Sciarini, 2007). Government bills submitted to 
the parliament for its consideration are accompanied by an explanatory report (i.e., Botschaft des Bundesrates or Message du Conseil fédéral). These reports provide a way to capture substantial issue attention by the Swiss government and are published weekly in the Federal Gazette. The 2-3 page summaries at the beginning of each report were retained to assign CAP topics.

The legislation dataset focuses on primary legislation adopted by parliament and subject to either mandatory or optional referendum. These legislative acts consequently include amendments to the federal Constitution, federal laws, federal decrees, and ratification of international treaties.

The direct democracy dataset includes all direct democratic votes that were held since the creation of the modern federal state in 1848 . That is, it includes all legislative acts submitted to the people as a result of mandatory referendum, optional referendum, or popular initiative.

The media dataset is based on the front page of the quality newspaper Neue Zürcher Zeitung (NZZ). The NZZ is considered to be the reference newspaper of the political and economic elites and is known for its complete and in-depth coverage of international and Swiss politics. The dataset includes, on an everyother-day basis, front-page articles, as well as all news articles on the first page of the national news section, and the main article(s) in the economy section referred to on the front page. CAP topics were assigned on the basis of the articles' full text. The data also provides information on whether articles focused on international, national or cantonal, and local news.

\subsection{Direct Democracy and Agenda-Setting}

Switzerland is often pointed out as the emblematic case of direct democracy. On the one hand, citizens may launch a popular initiative, introducing in this way a new policy proposal in the ballot. On the other hand, the referendum allows citizens to have the last say in relation to policies, since this instrument allows them to veto a constitutional amendment or a law adopted by the parliament. In other words, the direct democratic instruments can be activated in a top-down manner by political elites' decisions or, on the contrary, as a result of bottom-up pressure through the collection of citizens' signatures.

Since the 1990s, direct democracy has been increasingly activated. During the period 1990-2014, 234 policy proposals were placed on the ballot for the consideration of citizens. Roughly two-thirds of these policy proposals were the result of bottom-up pressure. These consisted of popular initiatives seeking policy change (42 percent) and optional referenda (32 percent) attempting to block policy change. The top-down agenda-setting by political elites was composed of mandatory referenda on constitutional amendments (20 percent) and counter-proposals (6 percent). 
Figure 18.1 presents the share of policy domains on the direct democratic agenda, considering top-down and bottom-up votes separately. Given the relative low number of popular votes, the twenty-one major topics of the CAP have been regrouped into six domains. ${ }^{2}$ Results show that the direct democratic arena has been activated the most frequently in relation to welfare and education issues (27 percent) and environment, energy, and transportation (21 percent). These two set of issues account for almost half of all the popular votes in the years 1990-2014.

Looking at the prioritization in terms of top-down and bottom-up agendasetting shows similarities and differences across policy domains. Despite the difference in intensity, welfare and education remains at the top of both topdown (23 percent) and bottom-up (29 percent) popular votes. In contrast, two policy domains seem particularly desynchronized between the two direct democratic agendas. Government and macro-economy issues are relatively more prominent in the top-down agenda, while foreign policy and defense occupies a larger share of bottom-up popular votes.

In terms of policy implications of bottom-up agenda-setting, around 13 percent of the popular initiatives summoned to the ballot successfully translated into policy change. This relatively low rate of success contrasts with that of top-down policy reforms: 73 percent of the objects placed on

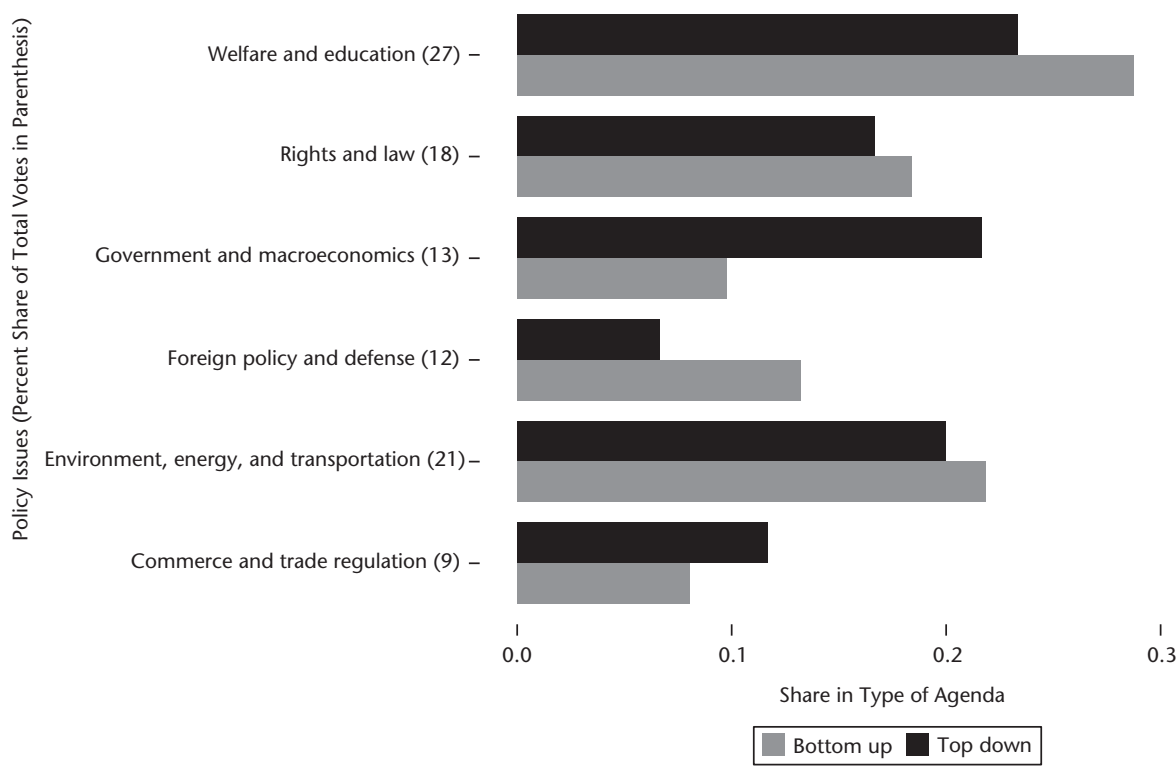

Figure 18.1. Policy issues of top-down and bottom-up direct democratic votes (1990-2014)

Source: Comparative Agendas Project-Switzerland 
the ballot in the form of mandatory referendum and counter-proposals were accepted. In a similar vein, 71 percent of the legislative acts adopted by parliament and challenged by an optional referendum were accepted by citizens and therefore enacted (i.e., success for the political elite). In short, these bivariate figures suggest that while agenda-setting in direct democracy is fundamentally shaped by bottom-up pressure, policy change is still primarily top-down driven. However, this last statement needs some qualification, as Switzerland is also changing in that respect: over the last ten years the Swiss People's party has enjoyed an unusual rate of success with popular initiatives in the field of foreign and immigration policy (Varone et al., 2014).

\section{Notes}

1. The data was collected with the financial support of the Swiss National Science Foundation under the projects "Agenda-Setting in Switzerland" (grant number 105511-119245/1), sponsored as part of European Science Foundation EUROCORES "The Politics of Attention: West European Politics in Time of Change," and "The Mediatization of Political Decision Making," sponsored as part of the National Center of Competence in Research "Challenges to Democracy in the 21st Century."

2. The domains have been regrouped following the CAP major categories as follows: foreign policy and defense: 16, 19; energy, environment, and transportation: 7, 8, 10, 14, 21; government and macro-economy: 1, 20; welfare and education: 3, 5, 6, 13, 23; rights and law: 2, 9, 12; economic and trade regulation: 4, 15, 17, 18.

\section{References}

Bailer, S. (2011). People' s Voice or Information Pool? The Role of, and Reasons for, Parliamentary Questions in the Swiss Parliament. The Journal of Legislative Studies, 17(3): 302-14.

Gava, R., Sciarini, P., and Varone, F. (2017). Who Europeanizes Parliamentary Attention, on Which Issues and How? A Policy Agenda Perspective. Journal of Legislative Studies, 23(4): 566-93.

Gava, R., and Varone F. (2012). So Close, Yet So Far? The EU's Footprint in Swiss Legislative Production. In The Europeanization of Domestic Legislatures: The Empirical Implications of the Delors' Myth in Nine Countries, ed. S. Brouard, O. Costa, and T. König. New York: Springer, 197-221.

Gava, R., and Varone F. (2014). The EU's Footprint in Swiss Policy Change: A Quantitative Assessment of Primary and Secondary Legislation (1999-2012). Swiss Political Science Review, 20(2): 216-22.

Kriesi, H., and Trechsel, A. (2008). The Politics of Switzerland: Continuity and Change in a Consensus Democracy. Cambridge: Cambridge University Press. 
OUP UNCORRECTED PROOF - FIRST PROOF, 14/11/2018, SPi

Roy Gava, Pascal Sciarini, Anke Tresch, and Frédéric Varone

Lijphart, A. (1999). Patterns of Democracy: Government Forms and Performance in Thirty-Six Countries. New Haven: Yale University Press.

Sciarini, P. (2007). The Decision-Making Process. In Handbook of Swiss Politics, ed. U. Klöti, P. Knoepfel, H. Kriesi et al. Zurich: NZZ, 465-99.

Sciarini, P., Fischer, M., and Traber, D. (2015). Political Decision-Making in Switzerland: The Consensus Model under Pressure. London: Palgrave Macmillan.

Sciarini, P., Nicolet, S., and Fischer, A. (2002). L'impact de l'internationalisation sur les processus de décision en Suisse: Une analyse quantitative des actes législatifs 1995-1999. Swiss Political Science Review, 8: 1-34.

Sciarini, P., and Tresch, A. (2014). Votations populaires. In Manuel de la politique suisse, ed. P. Knoepfel, Y. Papadopoulos, P. Sciarini et al. Zurich: NZZ, 497-524.

Tresch, A., Sciarini, P., and Varone, F. (2012). Media, Politics, and Policymaking: Lessons from Switzerland. Perspectives on Europe, 42(2): 29-34.

Tresch, A., Sciarini, P., and Varone, F. (2013). The Relationship between Media and Political Agendas: Variations across Decision-Making Phases. West European Politics, 36(5): 897-918.

Varone, F., Engeli, I., Sciarini, P., and Gava, R. (2014). Agenda-Setting and Direct Democracy: The Rise of the Swiss People's Party. In Agenda Setting, Policies, and Political Systems: A Comparative Approach, ed. C. Green-Pedersen and S. Walgrave. Chicago: University of Chicago Press, 105-22.

Vliegenthart, R., Walgrave, S., Wouters, R. et al. (2016a). Do the Media Set the Parliamentary Agenda? A Comparative Study in Seven Countries. European Journal of Political Research, 55(2): 283-301.

Vliegenthart, R., Walgrave, S., Wouters, R. et al. (2016b). The Media as a Dual Mediator of the Political Agenda-Setting Effect of Protest: A Longitudinal Study in Six Western European Countries. Social Forces, 95(2): 837-59. 